\title{
American foulbrood incidence in some US and Canadian honeys
}

\author{
KH Steinkraus, RA Morse
}

Department of Entomology, Comstock Hall, Cornell University, Ithaca, New York, NY 14853, USA

(Received 24 January 1992; accepted 5 June 1992)

\begin{abstract}
Summary - Eighty-two samples of honey supplied by American and Canadian honey producers were tested by the Hansen method for the presence of American foulbrood (Bacillus larvae) spores. Seven $(8.5 \%)$ were found to be positive. It was confirmed that the Hansen method is rapid and reliable. We believe it will be useful in screening individual colonies to determine which hives should be carefully inspected and/or treated to prevent potential economic loss from American foulbrood.
\end{abstract}

American foulbrood / Bacillus larvae / honey / honey bee colony / Hansen method

\section{INTRODUCTION}

American foulbrood, caused by Bacillus larvae White, is a serious disease of honey bees around the world resulting in considerable economic losses to beekeepers. The disease can be controlled with antibiotics but treatment costs money and is time-consuming. It would be less expensive if antibiotics could be applied only to colonies with visible signs of the disease or where the $B$ lanvae spore count is high. Detection of spores of $B$ larvae in honey has not been easy in the past as the microorganisms are fastidious, requiring a highly nutritious growth medium (Shimanuki et al, 1965). Experiments by Hansen $(1984 a, b)$ have demonstrated that the relativey simple, direct inoculation of undilut- ed honey onto a suitable medium can be used to detect the presence of $B$ larvae spores in honey. Hansen's method makes it possible, for the first time, to check honeys from individual hives for the presence of $B$ lanvae and to predict the desirability of using an antibiotic treatment for control in individual hives.

Sturtevant $(1932,1936)$ reported that a minimum of 50000 spores $/ \mathrm{ml}$ honey was required for detection. In his tests, 15 $(8 \%)$ of 187 honey samples tested were found to be positive for $B$ larvae. Shimanuki (1963) reported that $<10 \%$ of $B$ larvae spores will germinate and produce visible colonies in vitro. Shimanuki and Knox (1988) determined that approximately $100 \mathrm{~B}$ larvae spores were required to produce growth on brain heart infusion 
agar medium (at $37^{\circ} \mathrm{C}$ and a $72-\mathrm{h}$ incubation period). They detected $B$ larvae in $100 \%$ of commercially-packed honeys, but in only $30 \%$ of beekeeper-packed honeys. Their method involved dilution of the honey, dialysis, centrifugation, resuspension, and heat-shocking at $80^{\circ} \mathrm{C}$ for $10 \mathrm{~min}$, followed by spreading on the agar plate. Unfortunately, they did not indicate how they identified $B$ larvae colonies.

The Australasian Beekeeper (Editor, 1990), reported a method for the detection of $B$ larvae spores that involved dilution of the honey sample with saline, centrifugation to collect the spores, and heating to $80^{\circ} \mathrm{C}$ for $15 \mathrm{~min}$ to destroy vegetative contaminants and activate the spores. Nalidixic acid, an antibiotic, was added to the medium to suppress the growth of $B$ alvei. The medium used was not specified, neither was the incubation temperature and time. The Australians tested 393 packingplant honey samples. $B$ larvae was found in $10.11 \%$ of the samples. They concluded that the procedure was an effective diagnostic tool for American foulbrood identification.

Hansen (1984a, b) developed a method in which honey was spread directly on the surface of an agar medium containing $5 \mathrm{~g}$ tryptone, $15 \mathrm{~g}$ yeast extract, $20 \mathrm{~g}$ agar, $3 \mathrm{~g}$ $\mathrm{K}_{2} \mathrm{HPO}_{4}$, and $2 \mathrm{~g}$ glucose/l demineralized water. The honey samples were heated to a minimum of $60^{\circ} \mathrm{C}$ for $30 \mathrm{~min}$, to as high as $88-92{ }^{\circ} \mathrm{C}$ for $5 \mathrm{~min}$ (effective time) and sometimes to $100{ }^{\circ} \mathrm{C}$ to eliminate vegetative cells. The controls were honey samples known to contain $B$ larvae. Incubation was at $36^{\circ} \mathrm{C}$ usually for $1-6$ (maximum of 11) days. A standard loop was used for spreading the honey over the agar plate surface. On average, it delivered $80 \mathrm{mg}$ honey to the plate surface. Based on studies of honeys inoculated with known numbers of $B$ larvae spores, honeys containing $>2000$ spores/g honey will yield a positive result (Hansen, 1984a). Each $B$ larvae colony produced on a plate is equivalent to 1000-3000 spores/g honey. Triplicate plates were used per sample of honey. $B$ larvae was confirmed by the production of typical colonies, by microscopic examination of stained smears to reveal typical rods, and by examination for typical spores under phase microscopy. These studies provided a method whereby large numbers of honey samples can be checked rapidly for B larvae spores.

Hansen (1984b) found that 74 of 131 samples $(56.4 \%)$ of honeys from around the world contained $B$ larvae spores; 61 of $75(81 \%)$ foreign honeys contained $B$ larvae spores; 13 of $56(23 \%)$ of Danish honeys were positive for $B$ larvae.

The above-mentioned author (Hansen, 1986) tested 532 samples of honey. Of these, 521 samples were honeys from apiaries showing no clinical symptoms of American foulbrood (AFB) either during the year the sample was collected or the following year. However, 47 samples (9.0\%) contained $B$ larvae spores. Eleven samples of honey were tested from apiaries showing clinical signs of AFB. Nine samples $(81.8 \%)$ contained $B$ larvae spores. The numbers of spores of $B$ lanvae triggering AFB varied. The disease was found in apiaries from which honeys in some cases contained from 6000-12000 spores/g. One apiary produced honey containing 3000000 spores/g but showed no clinical symptoms of the disease. These data suggest that there may be a strong genetic component of American foulbrood resistance. In most cases, spores of $B$ larvae were found in the honey the year before an outbreak of AFB.

The purpose of our study was to test the Hansen method as an efficient, reliable method of detecting AFB spores in American honeys, mainly samples from eastern North America. 


\section{MATERIALS AND METHODS}

A modified Hansen's method was used. Hansen's medium contains (per l) $20 \mathrm{~g}$ agar, $5 \mathrm{~g}$ tryptone, $15 \mathrm{~g}$ yeast extract, $3 \mathrm{~g} \mathrm{~K}_{2} \mathrm{HPO}_{4}$ and $2.0 \mathrm{~g}$ glucose. The water used in the medium was demineralized. The medium was sterilized at $121^{\circ} \mathrm{C}$ for $15 \mathrm{~min}$.

Approximately $20 \mathrm{ml}$ of agar medium were poured into each Petri plate aseptically and allowed to set. About $80 \mathrm{mg}$ of honey was streaked over as much of the agar plate surface as possible with a standardized platinum loop. The starting honey was heated to a temperature of $80^{\circ} \mathrm{C}$ for $10 \mathrm{~min}$ prior to inoculation to destroy vegetative bacterial cells that are occasionally present and which may overgrow plates before $B$ larvae spores can germinate and grow. The heating also activates the germination of $B$ larvae spores. Cultures were incubated at $30{ }^{\circ} \mathrm{C}$ and counted at daily intervals for at least 6-10 days. Honey samples with a known content of $B$ larvae spores were utilized as positive controls in all experiments. $B$ larvae colonies were identified by typical colony form, microscopic examination of Gram-stained smears, examination of cells and spores under phase contrast microscopy, and a negative catalase reaction when flooded with $3 \% \mathrm{H}_{2} \mathrm{O}_{2}$.

Eighty-two honey samples were obtained from 44 different apiaries and commercial honey producers in 12 states: New York (47), Pennsylvania (12), Massachusetts (6), Connecticut (1), New Jersey (1), Georgia (1), Ohio (6), North Carolina (1), Rhode Island (1), Virginia (1), Maryland (1), Michigan (1) and Ontario, Canada (3). Duplicate plates of Hansen's medium were streaked with single loops of honey from the various samples of honey.

\section{RESULTS}

Hansen's method proved to be reliable and easily applied. Colonies that grew in 24-48 $h$ were not $B$ larvae and consisted of environmental bacteria present in the honey. If present, $B$ larvae spores germinated and colonies grew after 3-5 days. They appeared as a typical "bloom". Seven of 82 honey samples $(8.5 \%)$ contained $B$ larvae spores. Six of the positive samples were from New York State; one was from Pennsylvania. $B$ larvae counts ranged from 10 25 colony forming units (cfu)/g honey in 3 samples, $320-440 \mathrm{cfu} / \mathrm{g}$ honey in one sample, 560 to $>3000 \mathrm{cfu} / \mathrm{g}$ honey in $2 \mathrm{sam}$ ples, and to 2540 to $4000 \mathrm{cfu} / \mathrm{g}$ honey in one sample. If one uses the probable numbers of $B$ larvae spores/cfu (Hansen, $1984 a, b)$, the actual numbers of $B$ lanvae spores in the honey samples ranged from 10000 to $12000000 / \mathrm{g}$ honey (each colony representing 1000 to 3000 spores $/ g$ honey).

The remaining honey samples $(91.5 \%)$ showed no growth of $B$ lanvae colonies. However, 3 samples of honey contained bacteria, not $B$ larvae at levels of $>3000$ $\mathrm{cfu} / \mathrm{g}$. Five samples of honey showed no microbial growth on Hansen's medium.

\section{CONCLUSIONS}

The purpose of this study was to test the Hansen method as a reliable, efficient means of detecting AFB spores in individual honey samples. Results indicate that it is a reliable method of detecting $B$ larvae. Bacteria other than $B$ larvae generally grow on the inoculated plates within 2 days. $B$ larvae, on the other hand, grows and appears as "bloom" of typical colonies in 3-6 days. The colonies have a characteristic appearance and when exposed to a drop of $3 \% \mathrm{H}_{2} \mathrm{O}_{2}$ release no oxygen. They are catalase-negative. Microscopic examination reveals typical rods and a few spores. Thus, it is our conclusion that the Hansen method can be used to check individual hives and honey samples for the presence of $B$ larvae rapidly and efficiently.

Résumé - Présence de spores de loque américaine dans certains miels des États-Unis et du Canada. On a testé 
à l'aide de la méthode de Hansen la présence de spores de Bacillus larvae (BL), agent de la loque américaine (AFB), dans 82 échantillons de miel fournis par des producteurs de miels des USA et du Canada. Sept analyses $(8,5 \%)$ se sont révélées positives. Le milieu d'Hansen a la composition suivante : pour 1 I d'eau déminéralisée $20 \mathrm{~g}$ de gélose, $5 \mathrm{~g}$ de tryptone, $15 \mathrm{~g}$ d'extrait de levure, $3 \mathrm{~g}$ de $\mathrm{K}_{2} \mathrm{HPO}_{4}$ et $2,0 \mathrm{~g}$ de glucose. Le milieu est stérilisé à $121^{\circ} \mathrm{C}$ pendant $15 \mathrm{~min}$.

Vingt $\mathrm{ml}$ environ du milieu gélosé sont déposés dans chaque boîte de Petri en conditions aseptiques et mis à solidifier. Le miel (environ $80 \mathrm{mg}$ ) est étalé sur une surface de gélose aussi grande que possible à l'aide d'un anneau en platine standardisé. Le miel a été chauffé à $80^{\circ} \mathrm{C}$ avant l'inoculation afin de détruire toute cellule bactérienne éventuellement présente et susceptible de couvrir les boîtes avant que les spores de BL ne germent et croissent. Le chauffage a aussi pour action d'activer la germination des spores de BL. Les cultures sont mises à incuber à $30^{\circ} \mathrm{C}$ et les comptages sont faits quotidiennement durant 6-10 j. Des échantillons de miels renfermant une quantité connue de spores de $\mathrm{BL}$ sont utilisés comme témoins positifs. Les colonies de $\mathrm{BL}$ sont identifiées d'après la forme typique de la colonie, par examen microscopique de frottis colorés par la méthode de Gram, par examen de cellules et de spores en microscopie à contraste de phases et par la réaction de catalase négative après submersion par $\mathrm{H}_{2} \mathrm{O}_{2}$ à $3 \%$. Nos résultats prouvent qu'il s'agit d'une méthode fiable pour détecter les $\mathrm{BL}$. Les bactéries autres que $B L$ se développent généralement en 2 j dans des boîtes inoculées. BL, par contre, se développe et apparaît sous forme d'une "floraison" de colonies typiques en 3-6 j. Les colonies ont un aspect typique et, lorsqu'on les expose à une goutte de $\mathrm{H}_{2} \mathrm{O}_{2}$ à $3 \%$, ne dégagent pas d'oxygène, prouvant ainsi qu'elles sont catalase négatives. L'examen microscopique montre des batonnets et des spores typiques. Nous en concluons que la méthode de Hansen peut être utilisée pour vérifier la présence de BL dans les colonies et les échantillons de miel avec rapidité, efficacité et à un coût relativement faible.

loque américaine / Bacillus larvae / miel / colonie d'abeilles / méthode Hansen

Zusammenfassung - Vorkommen von
Sporen der Amerikanischen Faulbrut in
einigen Honigen aus den Vereinigten
Staaten und Kanada. Honigproduzenten aus den USA und Kanada stellten $82 \mathrm{Ho}-$ nigproben zur Verfügung, um sie durch die Hansen-Methode nach dem Vorkommen von Sporen der Amerikanischen Faulbrut (AFB; Bacillus larvae, BL) zu untersuchen. Sieben Proben $(8,5 \%)$ waren positiv. Hansen's Nährmedium enthält per Liter 20 g Agar, $5 \mathrm{~g}$ Trypton, $15 \mathrm{~g}$ Hefe-Extrakt, $3 \mathrm{~g}$ $\mathrm{K}_{2} \mathrm{HPO}_{4}$ und $2 \mathrm{~g}$ Glukose. Das für das Medium benutzte Wasser war destilliert. Das Nährmedium wurde $15 \mathrm{~min}$ bei $121^{\circ} \mathrm{C}$ sterilisiert.

Etwa $20 \mathrm{ml}$ des Agarmediums wurden unter aseptischen Bedingungen je Petrischale ausgegossen und zum Erstarren gebracht. Dann wurden etwa $80 \mathrm{mg}$ Honig mittels einer standardisierten Platinöse möglichst gleichmäßig über die gesamte Oberfläche der Platte ausgestrichen. Vor der Bebrütung wurden die Kulturplatten auf $80^{\circ} \mathrm{C}$ erhitzt, um vegetative Bakterienzellen zu zerstören, die gelegentlich vorhanden waren und möglicherweise die Platten vor der Keimung und Vermehrung der BLSporen überwachsen könnten. Die Kulturen wurden bei $30^{\circ} \mathrm{C}$ inkubiert und täglich für mindestens 6-10 Tage kontrolliert. Bei allen Experimenten wurden bekanntermaBen BL-Sporen enthaltende Honige als positive Kontrollen benutzt. BL-Kolonien 
wurden nach der typischen Kolonieform, mikroskopischen Untersuchungen gramgefärbter Ausstriche, Untersuchung der Zellen und Sporen unter einem phasenkontrast-Mikroskop und der negativen Katalase-Reaktion nach Übergießen mit 3\% $\mathrm{H}_{2} \mathrm{O}_{2}$ bestimmt.

Unsere Ergebnisse zeigen, daß dies eine verläßliche Methode zur Entdeckung von Bacillus larvae-Sporen ist. Andere Bakterien als $\mathrm{BL}$ wachsen im allgemeinen auf den beimpften Platten innerhalb von zwei Tagen. $\mathrm{Bl}$ hingegen erscheint als eine "Blüte" von typischen Kolonien erst innerhalb von 3-6 Tagen. Die Kolonien haben ein typisches Aussehen und sie geben nach Berührung mit $\mathrm{H}_{2} \mathrm{O}_{2}$ keinen Sauerstoff $a b$, womit bestätigt wird, daß sie Katalase-negativ sind. Die mikroskopische Untersuchung ergibt typische Zöpfe und typische Sporen. Wir kommen deshalb zu dem Schluß, daß die Hansen-Methode rasch, verläßlich und mit relativ geringen Kosten zur Prüfung einzelner Bienenvölker und Honigproben auf die Anwesenheit von BL eingesetzt werden kann.

\section{Amerikanische Faulbrut / Bacillus larvae / Honig / Bienenvolk / Hansen Methode}

\section{REFERENCES}

Editor (1990) Honey sampling for American foulbrood (AFB). Austr Beekeeper 91, 453

Hansen $\mathrm{H}$ (1984a) Methods for determining the presence of the foulbrood bacterium, Bacillus larvae, in honey. Dan J Plant Soil Sci 88, 325-328

Hansen $H$ (1984b) The incidence of the foulbrood bacterium, Bacillus larvae, in honeys retailed in Denmark. Dan J Plant Soil Sci 88, 329-336

Hansen $H$ (1986) The investigation of honey from bee colonies for Bacillus larvae. Dan $J$ Plant Soil Sci 90, 81-86

Shimanuki $H$ (1963) In vitro and in vivo studies of Bacillus larvae. Ph D Diss, lowa State Univ Sci Technol, Ames, lowa

Shimanuki H, Knox DA (1988) Improved method for the detection of Bacillus larvae spores in honey. Am Bee J 128, 353-354

Shimanuki $\mathrm{H}$, Hartman PA, Rothenbuhler WC (1965) In vitro growth studies of Bacillus larvae White. J Invertebr Pathol 7, 437-441

Sturtevant AP (1932) Relation of commercial honey to the spread of American foulbrood. $J$ Agric Res 45, 257-285

Sturtevant AP (1936) Quantitative demonstration of the presence of spores of Bacillus larvae in honey contamined by contact with American foulbrood. J Agric Res 52, 697-704 